\title{
Jedzenie i granice sztuki. Wprowadzenie
}

Bywało, że Wisława Szymborska w spożywczym kupowała to, co się jej podobało, dosłownie! Decydowała się na kawałek sera, ponieważ miał efektowny zielony kolor, albo na ciasteczka ze względu na ich nazwę — „Brzydkie”. Taki ser i ciasteczka mogły być przy okazji smaczne, choć niekoniecznie, i pewnie odżywcze, ale te sprawy schodziły na dalszy plan. Noblistka, wypełniając konieczności życiowe, jednocześnie od nich się uwalniała, ponad rozkosz smaku stawiając przyjemność patrzenia lub nazywania, co jej sekretarz, Michał Rusinek, dobrotliwie ocenia jako podejście „nieco zbyt estetyzujące”.

„Docenianie żywności jest par excellence praktyką kulturową: smakować oznacza postrzegać lub rozpoznawać przez język, wyróżnienie smaku i cieszenie się nim lub niechęć wobec niego - wszystkie te procesy oparte są na wartościach kulturowych" ${ }^{2}$. Autorzy przytoczonego cytatu, Rachel Spronk i Christien Klaufus, podkreślają zależność smaku, między innymi, od podziałów klasowych, genderowych czy wieku. Podzielają oni w tym względzie ustalenia Pierre'a Bourdieu, który w Dystynkcji przekonuje, że kuchnia i smak są ważnym markerem pozycji społecznej i tożsamości oraz że nasze wybory estetyczne i kulinarne są z sobą sprzężone ${ }^{3}$.

W ostatnich latach toczy się burzliwa dyskusja wokół, zaniedbywanego dotychczas teoretycznie, zmysłu smaku ${ }^{4}$. Estetycy, kulturoznawcy, antropolodzy i znawcy sztuki pytają o status smaku wśród pozostałych zmysłów i o możliwość estetycznej waloryzacji praktyk kulinarnych. Do podjęcia tych zagadnień skłaniają teoretyków między innymi artyści, którzy do swojej twórczości wprowadzają jedzenie. Przedstawienie jedzenia w sztuce można śledzić od najdawniejszych czasów. Od lat trzydziestych XX wieku można obserwować istotny przełom polegający na tym, że produkty spożywcze zostały wykorzystane nie jako temat, ale

1 M. Rusinek, Nic zwyczajnego. O Wistawie Szymborskiej, Kraków 2016, s. 89.

2 R. Spronk, Ch. Klaufus, Taste, „Etnofoor” 24, 2012, nr 2, s. 9.

3 Por. P. Bourdieu, Dystynkcja. Społeczna krytyka władzy sadzenia, przeł. P. Biłos, Warszawa 2005.

${ }^{4}$ Najbardziej znaczących filozoficznych analiz smaku dokonała amerykańska feministka Carolyn Korsmeyer. Por. C. Korsmeyer, Making Sens of Taste: Food and Philosophy, London 1999; eadem, Gender w estetyce: wprowadzenie, przeł. A. Naher, Kraków 2008; eadem, The Taste Culture Reader. Experiencing Food and Drink, Oxford-New York 2005. 
jako tworzywo sztuki. Akty dzielenia się żywnością i napojami były, po pierwsze, wykorzystywane, aby poszerzyć zakres sztuki oraz, po drugie, aby krytycznie skomentować współczesną kulturę, zadając pytania o konsumpcję, ekologię, gościnność, tożsamość, kwestie gender i inne.

Sztuka współczesna dostarcza wielu przykładów swego mariażu z gastronomią. Dość wspomnieć, że tacy artyści jak Gordon Matta Clark czy Daniel Spoerii mieli restauracje. Clark założył swoją w 1970 roku w Nowym Jorku, a Spoerii w Düsseldorfie w 1968 roku. Dwa lata potem w tej samej kamienicy otworzył galerię sztuki i wystawiał tam między innymi słynne asamblaże zwane trap-pictures, które, od lat sześćdziesiątych XX wieku, komponuje z pozostałości po zjedzonym posiłku. Pozostając $\mathrm{w}$ przestrzeni restauracji, można też wspomnieć o performansie Alison Knowles, który odbywał się w restauracji Riss, w Nowym Jorku. Nosił on nazwę Identyczny lunch i polegał na codziennym zjadaniu takiego samego posiłku. Można by mnożyć nazwiska artystów, którzy gotują, ale mamy też słynnego kucharza, konceptualistę, którego świat sztuki zaprosił do swego grona. Twórca kuchni molekularnej Ferran Adrià w 2007 roku przyjął to zaproszenie i wziął równoprawny udział w jednym z najbardziej znaczących wydarzeń artystycznych - Documenta, w Kassel.

Podobieństwo jedzenia i sztuki można rozpatrywać w dwojaki sposób: analizując pracę kucharza pod kątem wartości estetycznych i artystycznych albo przyglądając się działaniu artystów, którzy dostrzegają potencjał sztuki w technikach kulinarnych lub wykorzystują produkty spożywcze jako nowe tworzywo. Oczywiście pojawia się pytanie, w jakim sensie sztuka kulinarna łączy się ze sztuką przez duże „s": czy to tylko przenośnia, gdy mówimy o sztuce gotowania, sztuce podawania do stołu, sztuce parzenia herbaty? Czy istnieje język opisujący estetyczny status jedzenia, który umożliwi spojrzenie na jedzenie i gotowanie jako na znaczące i głębokie doświadczenie estetyczne? Innymi słowy, główna wątpliwość domagająca się rozwiania brzmi następująco: czy i na jakich zasadach możliwe jest zbliżenie sztuki i życia codziennego?

Carolyn Korsmeyer, autorka Making Sense of Taste, podważa utrwalone w kulturze schematy wartościowania zmysłów i wykluczania zmysłów cielesnych z dociekań filozoficznych, jednocześnie nie chce podkopywać innych fundamentów zachodniego myślenia, tych odpowiedzialnych za wymaganie od sztuki, aby była bezinteresowna i nie wchodziła w zbytnią zażyłość z odbiorcą, po to by, zgodnie z tradycją sztuk pięknych, doświadczenie estetyczne pozostawało nacechowane dystansem. $Z$ jednej strony więc zdecydowanie potępia ona niską pozycję zmysłu smaku i przekonywująco argumentuje na rzecz wielowymiarowości i istotności smaku oraz konieczności włączenia go $\mathrm{w}$ domenę estetyki, z drugiej strony równie jednoznacznie wyklucza możliwość uznania jedzenia za sztukę. Przyznaje ona, że posiłki mają znaczenie symboliczne, przedstawiające, kognitywne i ekspresywne. Nie wystarcza to jednak, aby najbardziej złożony konceptualnie i efektowny wizualnie posiłek nazwać dziełem sztuki. Tym, co wedle amerykańskiej badaczki 
praktyki kulinarne mogłyby osiągnąć, jest status sztuki niższego rodzaju — sztuk stosowanych lub dekoracyjnych. Korsmeyer uważa jednak, że nie powinno to być celem miłośników kuchni. Przygotowywanie i dzielenie się pokarmami nie potrzebuje zewnętrznego emblematu sztuki, samo przez się jest autonomicznym, niezwykle istotnym oraz interesującym zjawiskiem w kulturze ${ }^{5}$.

Bardziej śmiały w stosunku do przeszłości jest Arnold Berleant, który w książce Przez-myśleć estetykę proponuje odrzucenie ,pojęciowych pozostałości po starych historycznych prądach"6 i radykalne przewartościowanie estetyki, co doprowadzić ma do ,ponownego ukształtowania strumienia pojęć"7. W krytyczny sposób przezwycięża on tradycję Kantowską, która opiera się na wyłączeniu estetyki z ,dziedziny natury i moralności i przygotowuje dla niej niezależną jurysdykcję w odrębnej sferze"8. Berleant uważa, że przyjęte przez Kanta założenia dotyczące natury piękna były obarczone pozaestetycznymi założeniami. Jego zdaniem nie jest to teoria adekwatna do sztuki współczesnej, a nawet w odniesieniu do sztuki tradycyjnej. W miejsce estetycznej autonomii i bezinteresowności proponuje on projekt estetyki zaangażowania. Amerykański estetyk uważa, że sztuka nie powinna być traktowana jako zewnętrzny wobec odbiorcy, niezależny obiekt. Podkreśla on, iż stanowi ona ciągłość z doświadczeniem, a co za tym idzie

Funkcjonuje [...] jako obecny i aktywny element zaangażowanego uczestnictwa w dziele, które jest oznaką tego, co estetyczne. Każdy przedmiot, który oddziałuje w ten sposób, jest dziełem sztuki lub czymś w rodzaju sztuki, każde doświadczenie, które łączy przedmiot i odbiorcę w nietranscendentalną percepcyjną jedność, jest estetyczne ${ }^{9}$.

W takim rozumieniu pojęcie sztuki wykracza poza ramy tak zwanych sztuk pięknych. W perspektywie proponowanej przez Berleanta znajduje się miejsce dla na przykład sztuki użytkowej, rzemiosła, ale także wszystkich innych działań obdarzonych ,pierwiastkiem ludzkiej kreatywności”, w tym sztuki kulinarnej. Jako że podstawową kategorią organizującą rozważania Berleanta jest doświadczenie, wpisuje się on w tradycję fenomenologiczną reprezentowaną przez M. Merleau-Ponty'ego i wizję sztuki, zaproponowanej przez amerykańskiego pragmatystę Johna Deweya.

Ustalenia autora Sztuki jako doświadczenia są też istotnym punktem odniesienia pracy badawczej dwóch autorów publikowanych w tym tomie - Richarda Shustermana i Nicoli Perulla. Zanim jednak bliżej przedstawię ich artykuły, zacznę od tekstu, który otwiera tom poświęcony estetycznemu uwikłaniu zmysłu smaku.

${ }^{5}$ C. Korsmeyer, Gender w estetyce, s. 121.

${ }^{6}$ A. Berleant, Prze-myśleć estetykę. Niepokorne eseje o estetyce i sztuce, przeł. M. Korusiewicz, T. Markiewska, Kraków 2007, s. VII.

7 Ibidem.

8 Ibidem, s. XI.

9 Por. ibidem, s. 149. 
Pierwszy artykuł tego zbioru, zatytułowany Figura czy forma? Punkt widzenia żoładka, wprowadza w rozważania Immanuela Kanta, filozofa, który zaważył na sposobie postrzegania smaku estetycznego i smaku gastronomicznego jako nieprzystających do siebie sfer. Rodolphe Gasché w błyskotliwy sposób analizuje ustalenia niemieckiego filozofa i ukazuje je z nowego punktu widzenia. Uważnie przygląda się, niekiedy traktowanym pobłażliwie, wypowiedziom Kanta dotyczącym kwestii kulinarnych i dochodzi do wniosku, że smak fizjologiczny ma zaskakująco istotne znaczenie dla Kantowskiego sposobu rozumowania.

Kolejne artykuły eksplorują możliwość zniwelowania, ugruntowanej teoretycznie od stuleci, opozycji jedzenia i sztuki. Richard Shusterman znajduje miejsce dla sztuki jedzenia w rozwijanej przez siebie nowej dyscyplinie filozoficznej — somaestetyce, Nicola Perullo zaś kreśli projekt epistenologii, który zakłada przewartościowanie kluczowej kategorii smaku. Robert Dobrowolski ujawnia zaplecze estetyczne kuchni fusion i molekularnej, Dominika Zagrodzka natomiast bada znaczenie procesów estetyzacji jedzenia w kulturze współczesnej. Jeśli ktoś wciąż pozostanie nieprzekonany co do powinowactwa jedzenia i sztuki, ostatecznym argumentem w prezentowanej dyskusji będą działania Anny Królikiewicz, opisane w ostatnim artykule tomu, dające żywy dowód na to, że kuchnia bywa sztuką.

Zajrzyjmy do zapowiadanych artykułów. Współczesną dyskusję filozoficzną rozpoczyna tekst Somaestetyka i gastronomia. Kilka myśli o sztuce jedzenia. Shusterman kontrastuje w nim zwykły akt jedzenia z przemyślaną i dopracowaną w wielu aspektach odpowiedzią na potrzebę głodu, którą określa sztuką jedzenia. Dociekania amerykańskiego pragmatysty ujawniają wiele poziomów interpretacji powszedniej czynności posilania się. Shusterman proponuje oryginalną analizę sztuki jedzenia, którą zwykle utożsamia się z umiejętnością harmonizowania smaków i prezentacji potraw. Autor Świadomości ciała natomiast szczególną uwagę poświęca procesom składającym się na cielesny wymiar aktu konsumpcji, który aby stać się sztuką, musi prowadzić do zaangażowania somatycznego podmiotu, co wymaga szczególnej uważności i wrażliwości.

Perullo jest jednym z pionierów filozoficznego badania zmysłu smaku. Publikowany tu artykuł, Mądrość smaku i smak mądrości. Od filozofii jedzenia do filozofowania jedzeniem, wskazuje na węzłowe momenty w jego dotychczasowych pracach, które ukazane zostają na tle rozwoju tej nowej ścieżki badawczej. Jak już wspomniano, podobnie jak Shusterman, Perullo czerpie inspiracje z prac Deweya. Jego podstawowa książka o estetyce smakowania nosi tytuł, który w thumaczeniu brzmi: Jedzenie jako doświadczenie ${ }^{10}$, co jest oczywistym, bezpośrednim nawią-

10 Pierwotnie książka ta ukazała się po włosku: N. Perullo, Il gusto come esperienza, Bra Slow Food Editore 2012. W 2016 roku wyszło w Columbia University Press jej angielskie tłumaczenie, zatytułowane Art as Experience.

Prace Kulturoznawcze 21, 2017, nr 2

(C) for this edition by CNS 
zaniem do Sztuki jako doświadczenia. Najnowsze dociekania włoskiego filozofa odchodzą od filozofii jedzenia na rzecz filozofowania jedzeniem. Zmienia on też koncepcję smaku, o którym nie chce mówić jako o umiejętności właściwej oceny, ale jako o zdolności ciągłego „dostrajania” się do środowiska. Ponieważ jest profesjonalnym znawcą win, rozważania teoretyczne osadza chętnie w praktyce degustacyjnej. Połączenie tych dwóch sfer oddaje on jako „epistenologie”.

Artykuł Roberta Dobrowolskiego, Wznioste i cielesne pożywienie w sztuce jedzenia i nie-jedzenia, pokazuje zależność między sztuką a kulinarnymi upodobaniami. Estetyczne wychowanie podmiotu odzwierciedla się bowiem, choć zazwyczaj nieświadomie, w jego żywieniowych zwyczajach i preferencjach. Indywiduum, inkorporując to, co Inne, zarówno jedzenie, jak i artystyczną materię czyjegoś dzieła, czyni to zawsze w tym samym stylu, który odpowiadając na traumatyczne i rozkoszne koleje jego niepowtarzalnego życia, przyjmuje jednak bardziej ogólną formę jednej z współczesnych, otaczających go sztuk. Dla jednych pociągający więc będzie perwersyjny, abiektualny dadaizm kuchni fusion, dla innych zaś - wzniosła, balansująca na krawędzi anoreksji, konceptualna kuchnia molekularna.

Podobna intencja przyświeca Dominice Zagrodzkiej. Jej artykuł Dlaczego jedzenie musi być piękne? przenosi wprawdzie dyskusje o estetycznym statusie żywności z poziomu dyskursu filozoficznego w obszar badań społeczno-kulturowych, ale tak samo jak Dobrowolski poszukuje ona ukrytych estetyk w dyskursach i praktykach kulinarnych. Autorka analizuje manifesty kucharzy, którzy swoje działania, określane mianem new cookery (nowa kuchnia), chętnie sytuują w kontekście praktyk artystycznych i doświadczenia estetycznego. Zagrodzka próbuje wyjaśnić obecność tych tendencji we współczesnej kulturze, odwołując się do koncepcji estetyzacji codzienności Wolfganga Welscha i rozważań Georga Simmla o estetyzacji procesów wspólnotowych.

Głos filozoficzno-antropologiczny uzupełnia esej Anny Królikiewicz, Kiedy wspomnienia staja się forma. Jedzenie jako medium $w$ praktykach site specific. Lektura tego tekstu daje bezpośredni wgląd w niezwykle zmysłowy świat wyobraźni najbardziej znaczącej obecnie artystki food artu w Polsce. Królikiewicz dzieli się motywacjami, jakie towarzyszyły powstaniu jej kilku prac. Łączy je przemyślane, staranne dobieranie przestrzeni ekspozycji, a także aktywne zaangażowanie zmysłów smaku i węchu, którym artystka wyznacza zadanie pobudzania „blednących folderów pamięci”.

Odwołanie do najnowszej książki podejmującej filozoficzny namysł nad smakiem znajduje się w dziale recenzji. Dominika Zagrodzka prezentuje w nim książkę Philosophers at Table. On Food and Being Human autorstwa Raymonda Boisverta i Lisy Heldke. 
Wyjątkowy charakter ma ostatnia część zbioru, archiwum zmysłów. Dzięki wspomnieniu Rodolphe’a Gaschégo mamy okazję poznać skład słynnej sałatki Derridy, którą chętnie spożywali dekonstrukcjoniści. Poprosiłam Annę Królikiewicz, aby przygotowała nową wersję tej przystawki i sfotografowała efekt swej pracy. Zwróćcie uwagę na sensualność zdjęcia i nadrealistyczne światło, które wydobywa smakowite składniki z mroku tła.

Dorota Koczanowicz 